\title{
Welcome to the Nordic Council of Ministers
}

- what we do and how we do it

III Nordic Council of Ministers 


\section{Welcome to the Nordic Council of Ministers \\ - what we do and how we do it}

ANP 2018:796

ISBN 978-92-893-5724-1 (PRINT)

ISBN 978-92-893-5725-8 (PDF)

ISBN 978-92-893-5726-5 (EPUB)

http://dx.doi.org/10.6027/ANP2018-796

(c) Nordic Council of Ministers 2019

Layout: Louise Jeppesen

Print: Rosendahls

Printed in Denmark

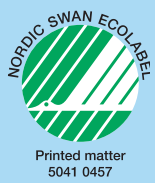

\section{Nordic co-operation}

Nordic co-operation is one of the world's most extensive forms of regional collaboration, involving Denmark, Finland, Iceland, Norway, Sweden, the Faroe Islands, Greenland, and Åland.

Nordic co-operation has firm traditions in politics, the economy, and culture. It plays an important role in European and international collaboration, and aims at creating a strong Nordic community in a strong Europe.

Nordic co-operation seeks to safeguard Nordic and regional interests and principles in the global community. Shared Nordic values help the region solidify its position as one of the world's most innovative and competitive.

Nordic Council of Ministers

Nordens Hus

Ved Stranden 18

DK-1061 Copenhagen

www.norden.org

Download and order Nordic publications from www.norden.org/nordpub 


\section{Welcome to the Nordic Council of Ministers}

- what we do and how we do it

iII Nordic Council of Ministers 


\section{Contents}

Welcome to the Nordic Council of Ministers

Introduction

History

The most integrated region in the world

Together We Are Stronger

Nordic synergy

Organisation and structure $\quad 21$

The prime ministers $\quad 21$

The councils of ministers $\quad 21$

The Presidency $\quad 24$

The Faroe Islands, Greenland and Åland $\quad 24$

The committees of senior officials 25

The Secretary General and the right of initiative $\quad 25$

The Secretariat 26

Nordic institutions and other bodies $\quad 28$

The Nordic Council of Ministers' international

co-operation 
Practical work $\quad 35$

Budget processes $\quad 35$

Example - Budget $2018 \quad 37$

Co-operation between the Presidency and

the Secretariat 38

Inter-sectoral co-operation 38

Languages and the Nordic Council of Ministers 39

Nordic Council $\quad 41$

About the Nordic Council $\quad 41$

Working with the Nordic Council $\quad 42$

The Nordic Council prizes $\quad 45$

Useful documents and abbreviations $\quad 46$

Useful documents and systems $\quad 46$

$\begin{array}{ll}\text { Abbreviations } & 47\end{array}$ 


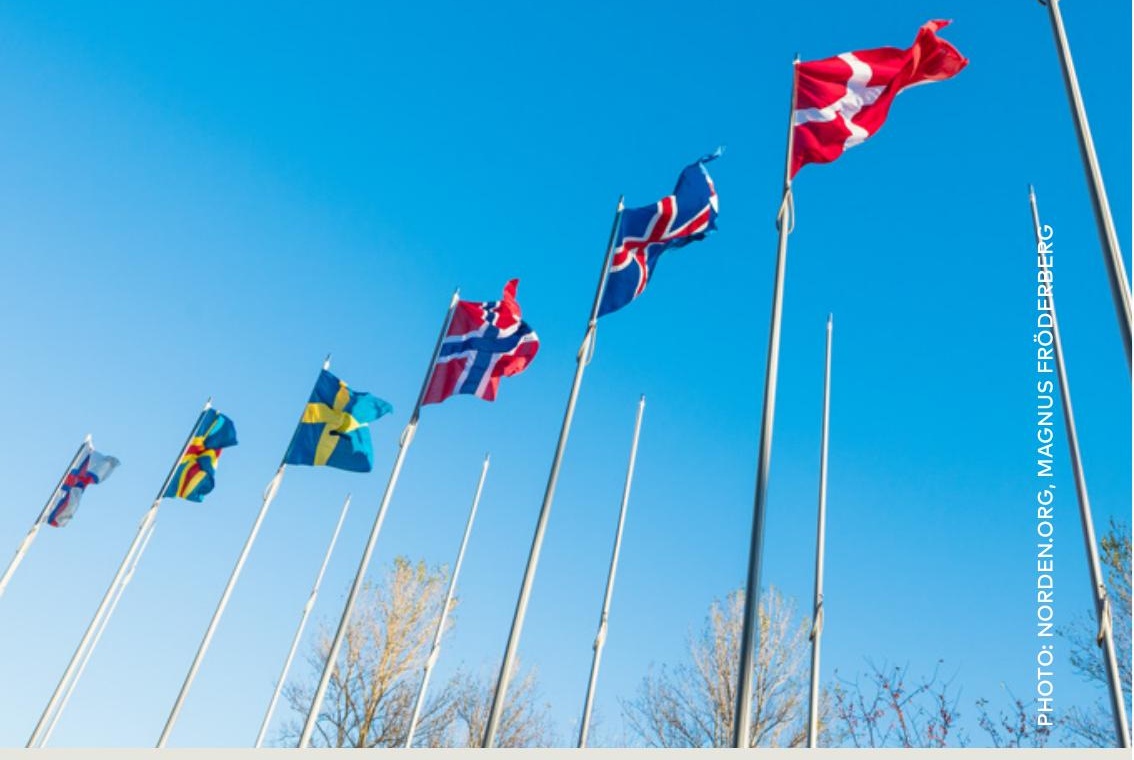

The Nordic Council of Ministers consists of the Nordic countries: Denmark, Finland, Iceland, Norway and Sweden. The Faroe Islands, Greenland and Åland also participate. 


\section{Welcome to \\ the Nordic Council of Ministers}

Nordic co-operation is unique in many ways. A similar closeness of relations between states is not found anywhere else in the world.

The Nordic project was launched in the aftermath of World War II. It was clear at the time that nationalism had reached the end of the road. It posed a threat not just to our dignity and culture, but to our very survival. In response, the Nordic countries started to co-operate more and more intensively, and Nordic co-operation is more wide-ranging than ever today. Global trends suggest it will need to be even closer in the future. Nordic solutions have never been in greater demand, so the starting point is good. The Region is extraordinarily rich in all sorts of resources. It tops many global indexes, and the development potential branches out into multiple areas.

In a world of economic inequality, financial problems and the cohesion of the international community under pressure, Nordic co-operation has never been more relevant. The nations of the world face the urgent challenge of finding political systems that counteract exclusion and 
promote social equality, competitiveness, sustainable growth and democracy. The Nordic model can serve as a source of inspiration for the many others who are interested in our experiences and the way we do things.

Nordic co-operation offers unique opportunities - for overcoming limitations, promoting openness, broadening horizons, providing inspiration and not automatically adopting a defensive posture when national differences become obvious. The Nordic Council of Ministers is an international organisation at the heart of the Region and its history. Our shared history covers so much - language, culture, politics, business and trade, and all the other mutual exchanges and interactions that have created the Nordic Region we know today. The Nordic Council of Ministers wants our similarities and differences to make our work more vital.

We have spent the last five years reforming the Nordic Council of Ministers. We want to continue generating results that are relevant to the governments, companies and people of the Nordic Region in the 21st century. We also want to provide effective support for the prime ministers' vision of the Nordic Region as the most integrated region in the world.

The New Nordic Region reforms build on the momentum for change that has epitomised Nordic co-operation in recent years, in order to produce tangible and lasting 
results. Strategic reviews have helped develop co-operation between the councils of ministers, and collaboration with the Nordic Council is now closer. The Nordic countries now co-operate more on international affairs, for example adopting joint positions on EU issues and in the global arena, as well as on profiling the Nordic Region and the prime ministers' initiative Nordic Solutions to Global Challenges.

The reforms have generated significant results and lay the foundation for further achievements in the years to come. The Nordic project has never been more exciting.

\section{Dagfinn Høybråten}

Secretary General of the Nordic Council of Ministers 


\section{Introduction}

The Nordic countries are linked together by their shared history. For almost a thousand years, they have alternated between working together, waging war on each other or forming unions, but peace has prevailed between the countries for the last two centuries.

\section{History}

Nordic co-operation is the world's oldest regional partnership. The first steps towards the formal political collaboration we know today were taken in the aftermath of World War II, leading to the establishment of the Nordic Council in 1952. Inter-governmental co-operation was formalised in 1971 with the establishment of the Nordic Council of Ministers. Like the United Nations, Nordic co-operation is inter-governmental by nature and operates on a consensus basis at all levels. In other words, the Nordic Council of Ministers works on what the countries agree to co-operate on.

People often have difficulty telling the Nordic Council and the Nordic Council of Ministers apart - and indeed, the two organisations, although separate, share an address in 
The Helsinki Treaty is the legal basis for official Nordic co-operation. Originally signed in 1962, it has been updated several times, most recently in 1996. 
Copenhagen. The Nordic Council is the inter-parliamentary body, the Council of Ministers is the inter-governmental body.

\section{The most integrated region in the world}

Dagfinn Høybraiten was given the mandate to reform the Nordic Council of Ministers when he took up the post of Secretary General in 2013. This led to the New Nordic Region reforms adopted by the Ministers for Nordic Cooperation (MR-SAM) in 2014 and 2016. The overall goal is to make Nordic co-operation fit for the future so that it continues to produce results relevant to the governments, companies and people of the Region.

In September 2016, based partly on this reform work, the prime ministers adopted an overall objective to make the Nordic Region the most integrated region in the world.

The groundbreaking agreements concluded during the first phase of co-operation (passport union, integrated labour market, single educational area and the social security convention) enabled Nordic citizens and companies to live, study, work and do business wherever they wished in the Region - long before the EU started to talk about freedom of movement.

To this day, a great deal of the co-operation still focuses on integration and cross-border mobility. The big exchange programmes (Nordplus, the Nordic-Baltic Mobility 


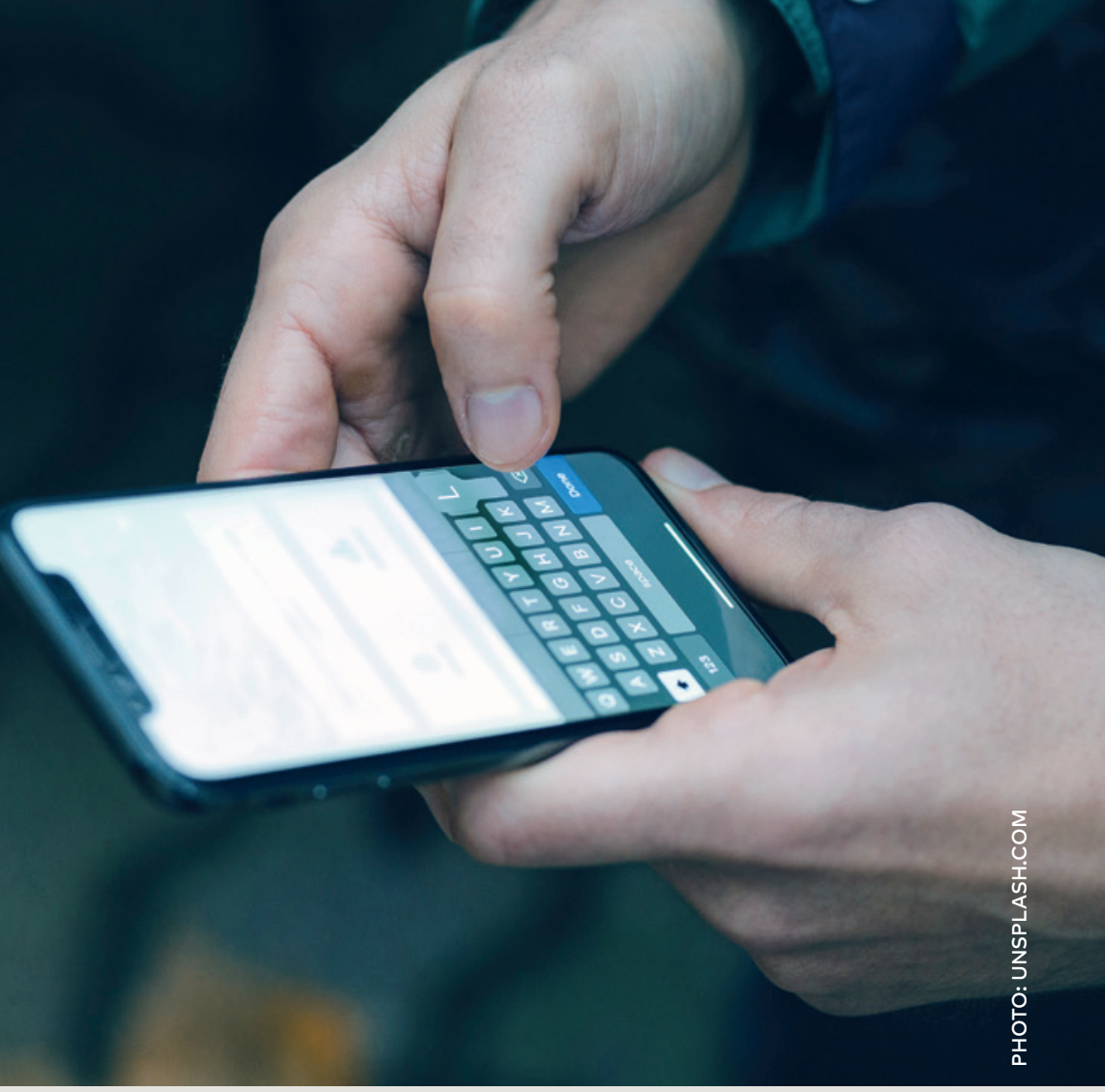

To learn more, visit www.norden.org, which features general information about Nordic co-operation, in-depth information about the Nordic Council of Ministers and links to Nordic newsletters. 
Programme for Culture, Nordjobb) send thousands of Nordic students, teachers and artists to other Nordic countries to study or work every year; the Freedom of Movement Council continues the key work of removing barriers to mobility, and initiatives are pursued to improve the framework conditions for free movement in the Region - to name some examples.

Nordic co-operation on digitalisation is one of the keys to progress. An ad hoc Nordic Council of Ministers for Digitalisation was set up in 2017. The aim is to integrate the Region digitally and make digital services accessible across all of the countries. A 'digital passport union' would facilitate freedom of movement for both people and companies.

\section{Together We Are Stronger}

In February 2014, the Ministers for Nordic Co-operation (MR-SAM) adopted a vision statement for co-operation and the Nordic Council of Ministers. Together We Are Stronger stresses that the experiences of the Nordic countries can be useful in other parts of a world in which regional co-operation is becoming more and more important. 
The vision acts as a guiding principle for the work of the Nordic Council of Ministers. It is based on four key pillars:

- Freedom of movement

- Innovation

- Visibility

- International engagement

The vision also provides guidelines for the use of the 'priority' budget, which funds new and large-scale initiatives that reflect the Nordic Council of Ministers' key political priorities. The priority budget for 2018 is approximately DKK 88 million, about half of which is earmarked for initiatives under the annual Presidency, the rest for priorities set by the prime ministers and MR-SAM. In 2017-19, the priority budget included the prime ministers' initiative Nordic Solutions to Global Challenges.

This initiative promotes innovation and Nordic solutions to the most pressing global problems. The prime ministers want to share the countries' knowledge from six flagship projects in the areas of climate and energy solutions, sustainable urban development, Nordic food, health, and gender equality in the labour market. The projects mobilise a broad range of experts, researchers, private-sector actors, Nordic embassies, export councils and international stakeholders to meet the heightened global interest in Nordic policies and products. 
The priority budget also funds a project to promote the international profile and position of the Nordic Region as part of the strategy adopted by MR-SAM in 2014. The Nordics runs initiatives, including at Nordic embassies around the world, that focus on spreading knowledge of the Region and our key values. The Council of Ministers has developed a digital platform full of stories, videos, facts and images that illustrate Nordic values in practice. The core of this branding is the five values that underpin Nordic cohesion: trust, openness, sustainability, innovation and gender equality. The Nordics has also turned traditional place branding on its head and shines a light on Traces of North elsewhere in the world.

The priority budget also pays for the work on the integration of refugees and immigrants that emerged in response to the wave of migration in 2015-16, when the countries faced similar challenges and agreed they could learn from each other, e.g. in areas like finding jobs for refugees and immigrants.

\section{Nordic synergy}

The concept of Nordic synergy is an important guiding principle for co-operation. The countries have a great deal to gain from working together, including making a greater impact at international level. In general, co-operation focuses on areas where a Nordic approach generates added value for the countries and peoples of the Region. 

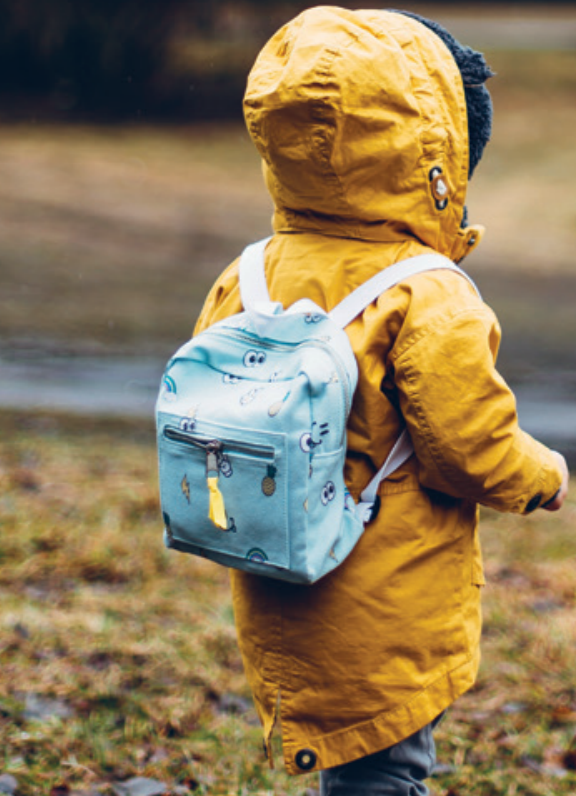

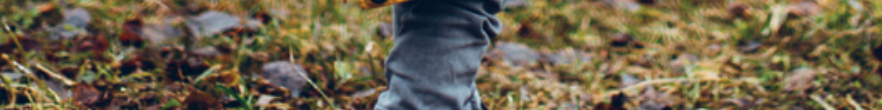
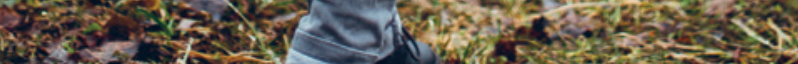

(2)

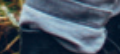

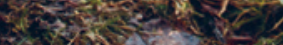

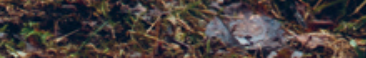

Nordic co-operation focuses on areas where a Nordic approach generates added value for the countries and peoples of the Region. 
Nordic activities must fulfil one or more of these criteria:

- they would otherwise be implemented by the national governments, but a Nordic approach would have clear positive effects

- they promote and develop the Nordic sense of affinity

- they enhance Nordic competences and competitiveness

- they enhance the Nordic Region's influence in the international community. 


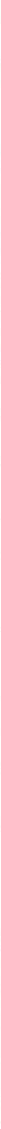

The Swan is the official logo of the Nordic Region. It is a recurring element in the branding of the Nordic Council of Ministers, the Nordic Council and all of the Nordic institutions, as well as the Nordic Council of Ministers' offices in the Baltic states and Russia. The feathers represent Denmark, Finland, Iceland, Norway, Sweden, the Faroe Islands, Greenland and Åland. 


\section{Organisation and structure}

\section{The prime ministers}

The prime ministers have the overall formal responsibility for Nordic inter-governmental co-operation but no formal schedule of meetings. In practice - and in accordance with the Helsinki Treaty - responsibility is delegated to the Ministers for Nordic Co-operation (MR-SAM). The prime ministers meet a couple of times a year, usually in early summer and during the annual Session of the Nordic Council.

\section{The councils of ministers}

The Nordic Council of Ministers is made up of representatives of Denmark, Finland, Iceland, Norway, Sweden, the Faroe Islands, Greenland and Åland. Despite the name, it actually consists of several councils of ministers. Like the $\mathrm{EU}$, the work is done by councils responsible for specific areas. The latest addition, the ad hoc Council of Ministers for Digitalisation, brings the number up to 11 . In addition, MR-SAM exercises overall responsibility on behalf of the prime ministers and is responsible for the overall budget of the Nordic Council of Ministers and a range of other coordinating functions. 


\section{List of councils of ministers:}

The Nordic Council of Ministers for Labour (MR-A) deals with inter-governmental co-operation on employment, the labour market, the working environment and labour law.

The Nordic Council of Ministers for Finance (MR-FINANS) promotes Nordic interests in international forums and pursues closer economic integration.

The Nordic Council of Ministers for Fisheries, Aquaculture, Agriculture, Food and Forestry (MR-FJLS) promotes the sustainable use of natural and genetic resources in these four policy areas.

The Nordic Council of Ministers for Gender Equality (MR-JÄM) draws on shared Nordic culture, history and democratic traditions to promote close and constructive co-operation on gender equality.

The Nordic Council of Ministers for Culture (MR-K) promotes diversity in cultural activities and spreads knowledge and information about artists and their work across national borders.

The Nordic Council of Ministers for Legislative Affairs (MR-LAG) promotes the sharing of certain fundamental principles in legislation throughout the Nordic Region.

The Nordic Council of Ministers for the Environment and Climate (MR-MK) seeks to preserve and improve the quality of the environment and life in the Region and to influence regional and international co-operation. 
The Nordic Council of Ministers for Health and Social Affairs (MR-S) focuses its work on the shared fundamental values that form the basis for the Nordic welfare model.

The Ministers for Nordic Co-operation (MR-SAM) have a mandate from the prime ministers and the Helsinki Treaty to coordinate inter-governmental co-operation.

The Nordic Council of Ministers for Education and Research (MR-U) has a remit to maintain the Region's position as a world leader in knowledge and skills.

The Nordic Council of Ministers for Sustainable Growth (MR-VAEKST) helps ensure continued strong economic growth in the Region.

The Nordic Council of Ministers for Digitalisation (MR-DIGITAL) works on the digital integration of the Nordic Region until 2020 and works closely with the Baltic states to keep the Nordic/Baltic region on the digital front line. 
All decisions taken by the councils of ministers are by consensus - in other words, all of the countries must agree. They meet once or twice a year, MR-SAM four or five times. After due consideration of cases, decisions are made either by a vote at a meeting, or in writing.

\section{The Presidency}

The Presidency of the Nordic Council of Ministers rotates between the five countries in turn. The Nordic Council also has a rotating presidency. The same country can never hold the presidency of both organisations at the same time.

The Presidency is responsible for the work done in the various areas of co-operation. An annual programme for the Presidency is drawn up to provide guidance for this work. It is usually presented at the annual Session of the Nordic Council in October/November. The country holding the Presidency is also responsible for various priority projects and has a special 'priority' budget for this purpose. The Presidency chairs all meetings of both the councils of ministers and the committees of senior officials.

\section{The Faroe Islands, Greenland and Åland}

The Helsinki Treaty specifies the role played by the Faroe Islands, Greenland and Åland in the Nordic Council of Ministers. In 2007, MR-SAM gave them a stronger role in Nordic co-operation based on the Åland Document. All three are entitled to speak at meetings of the councils of ministers, senior officials and working groups. They can 
also chair meetings when Denmark or Finland holds the Presidency. They have the right to attend and speak at all meetings but do not have voting rights.

\section{The committees of senior officials}

Each council of ministers has at least one committee of senior officials to prepare and follow up on the cases they consider. The Committee for Nordic Co-operation (NSK) services MR-SAM and has a corresponding overall level of responsibility for co-operation. The committees consist of civil servants who act as the ministers' representatives.

As they are responsible for more concrete work, the committees of senior officials meet more frequently than the councils of ministers - usually four to eight times per year.

\section{The Secretary General and the right of initiative}

The Nordic governments appoint the Secretary General of the Nordic Council of Ministers, whose job is to manage the Secretariat. Although the work of the Presidency and the Secretary General are subject to guidelines drawn up by NSK, under the rules of procedure for the Nordic Council of Ministers the Secretary General also has the right and duty to present initiatives deemed necessary to develop co-operation. This is known as the right of initiative and applies to all of the work done by the Secretariat. In other words, the Secretariat does not just have a passive role as the practical co-ordinator of decisions taken by councils of ministers and committees of senior officials; it also puts 
forward proposals and plays an active role in driving cooperation forward.

\section{The Secretariat}

The Secretariat of the Nordic Council of Ministers in Copenhagen is responsible for the day-to-day work of intergovernmental co-operation. Its primary task is to prepare cases to be discussed by committees of senior officials and councils of ministers. It is also responsible for ensuring that decisions are implemented. The Secretariat employs approximately 130 people from all over the Nordic Region.

In December 2013, the Secretariat adopted the following mission statement:

The Nordic Council of Ministers' Secretariat facilitates official inter-governmental co-operation that adds value and raises the profile of the Region at home and abroad by:

- initiating, implementing and following up on policy decisions

- generating knowledge on which to base Nordic solutions

- building networks to exchange information and ideas.

The mission statement represents a step toward realising MR-SAM's vision for co-operation - Together We Are Stronger - in the day-to-day work of the Secretariat. 
The work is done by six departments, three of which are specialist departments with responsibility for particular councils of ministers. Each of them has a head of department and a number of senior advisers, advisers, co-ordinators and student assistants as well as project staff on fixed-term contracts and assignments.

The Office of the Secretary General (GSK) helps the Secretary General direct and coordinate the work of the Secretariat, under the management of the Chief of Staff. GSK also provides support services for MR-SAM and NSK. The other councils of ministers are serviced by the specialist departments and the Department for HR, Administration and Law (HRAJ):

- The Department for Culture and Resources $(K R)$ is responsible for MR-K, MR-FJLS and MR-JÄM.

- The Department for Knowledge and Welfare (KV) is responsible for MR-U and MR-S.

- The Department for Growth and Climate (VK) is responsible for MR-VAEKST, MR-A, MR-MK and MR-FINANS.

- The Department for HR, Administration and Law (HRAJ) is responsible for MR-LAG.

In addition, the Communications Department (KOMM) is responsible for communication and information. The Nordic Council of Ministers and Nordic Council work together on communications, pooling resources to 
maximise public awareness of co-operation, e.g.

www.norden.org serves both bodies.

As part of the recent reform work, a Policy Analysis and Statistics Unit has been set up in GSK to conduct analyses and write reports as input into debates about the Nordic Region and Nordic co-operation and to support the Secretariat in its role as one of the engines of cooperation, including by providing statistical material about proposals.

When recruiting staff, efforts are made to achieve a balance between the countries without making the requirements for competence less strict. All Secretariat staff are on fixed-term contracts and the maximum total period of employment is eight years.

\section{Nordic institutions and other bodies}

Much of the work of Nordic co-operation is done by institutions based in the various countries. A total of 12 institutions and around 20 other bodies are funded by official Nordic co-operation. They account for approximately onethird of the Nordic Council of Ministers' total budget. The institutions cover areas defined by the governments. They are funded in whole or in part (in most cases more than $50 \%$ ) by the Nordic Council of Ministers. The rest of the funding comes mainly from national governments but also from European bodies and other funding sources. 
The institutions play an important role in the implementation of Nordic policies. One outcome of the New Nordic Region reforms is that the institutions are now more closely linked to policy work and the Secretariat in general. The heads of the institutions and the heads of the Secretariat departments form an Extended Management Group that meets approximately once a quarter. 
The Nordic institutions are:

- The Nordic House in Reykjavik (NOREY)

- The Nordic House in the Faroe Islands (NLH)

- The Nordic Institute in Greenland (NAPA)

- The Nordic Institute in Åland (NIPÅ)

- Nordic Culture Point (NKK) (Helsinki)

- Nordregio (Stockholm)

- Nordic Institute for Advanced Training in Occupational Health (NIVA) (Helsinki)

- NordForsk (Oslo)

- Nordic Innovation (Oslo)

- Nordic Energy Research (NEF) (Oslo)

- Nordic Welfare Centre (NVC) (Stockholm and Helsinki)

- Nordic Genetic Resource Centre (NordGen) (Alnarp, Ås, Svalbard)

In addition to the institutions, a number of other bodies are more loosely associated with the Nordic Council of Ministers. They are funded in whole or in part by the Nordic Council of Ministers.

Examples of other bodies involved in Nordic co-operation:

- The Nordic Ecolabel

- Nordisk Film \& TV Fond

- The Nordic Culture Fund (NKF)

- The Nordic Environment Finance Corporation (NEFCO)

- North Atlantic Co-operation (NORA) 


\section{The Nordic Council of Ministers' international co-operation}

The Nordic Council of Ministers works closely with a range of international, regional and national organisations in the Nordic Region and beyond. Development and growth in the Baltic region account for a large proportion of this international work. The Nordic Council of Ministers participates in and contributes to the implementation of the EU's Baltic Sea Strategy and the Northern Dimension. It also endeavours to make a contribution in other relevant contexts, e.g. the EU and the UN.

The Nordic Council of Ministers has worked closely with Estonia, Latvia, Lithuania and North-West Russia for many years from offices in Tallinn, Riga, Vilnius and Saint Petersburg. When this work started in the early 1990s, the focus was mainly on spreading information about the Nordic Region, but co-operation has developed and expanded in recent years.

Co-operation with the Baltic countries focuses on issues such as innovation, migration and integration, strengthening welfare and democracy, environmental and climate issues and combating human trafficking and organised crime. In recent years, the Nordic Council of Ministers has also supported balanced Russian-language media in the Baltic countries. 


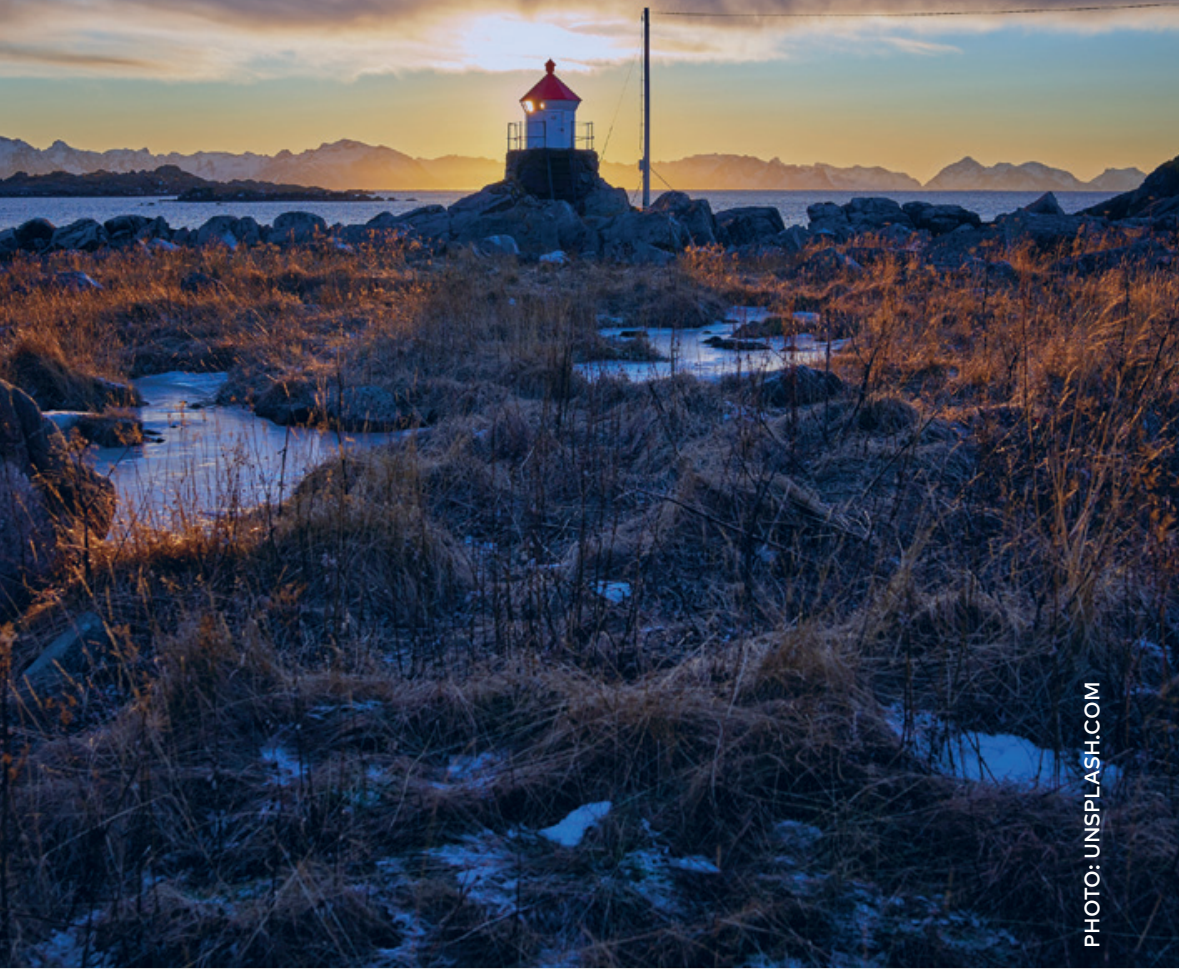

The Nordic Council of Ministers has observer status on the Arctic Council and pursues closer Nordic co-operation on Arctic affairs. 
The Nordic Council of Ministers' projects in Russia are now run by 'Nordic management bodies'. This is because the office in North-West Russia was registered as a 'foreign agent' under Russian law in 2015. The work includes promoting research, exchange programmes for MPs, media and journalist activities, environment and climate change, health promotion, disease prevention and information activities relating to the Nordic countries and Nordic co-operation. The office has been scaled down considerably, and no longer has responsibility for projects or other outreach activities. The Nordic Council of Ministers has challenged the registration requirement, which it sees as an impediment to important co-operation between neighbouring countries. We are currently in talks with the Russian authorities about a change to the status of the office.

The Nordic Council of Ministers has observer status on the Arctic Council and pursues closer Nordic co-operation on Arctic affairs in this context. It also works with the other countries around the Arctic and is now seeking to develop co-operation with our neighbours to the west, including the United States and Canada. The Council of Ministers is also pursuing closer relations with China in areas of common interest, including innovation, sustainable development, tourism, welfare solutions and culture. The Nordic Council of Ministers is often seen as a model for regional co-operation and is frequently invited to lectures and conferences around the world. 


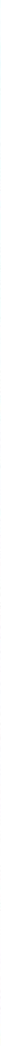

The annual cost of Nordic co-operation is approximately DKK 37 per citizen of the Region. 


\section{Practical work}

\section{Budget processes}

The Nordic Council of Ministers has a budget of approximately DKK 1 billion. It is almost entirely funded by national contributions according to a formula based on share of total Nordic gross national income. The formula is illustrated below:

\section{Funding formula 2018, \% of GNI}

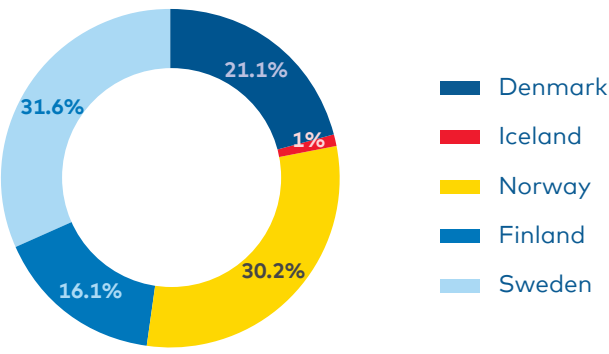




\title{
Budget 2018 was arrived at by the following process
}

\section{October 2016:}

Sectors input their priorities for budget 2018 .

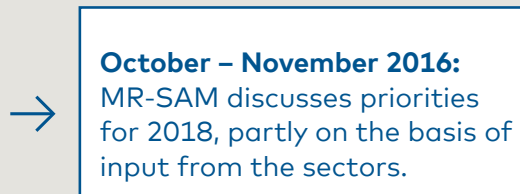

October - November 2016:

MR-SAM discusses priorities for 2018, partly on the basis of input from the sectors.

\section{October - November 2017}

(Nordic Council session): MR-

SAM adopts the final budget for 2018. The Nordic Council adopts its budget recommendation.

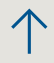

\section{Early September 2017:}

The Nordic Council of Ministers' proposal for budget 2018 is approved.

\section{February 2017:}

Budget allocations for 2018 are approved, including setting of total framework and amounts for individual sectors.

\section{$\nwarrow$}

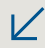

\begin{abstract}
June 2017:
The Secretary General's budget proposal is presented and submitted to the governments and the Nordic Council for consideration.
\end{abstract}

The budget must be approved by both the Nordic Council of Ministers and the Nordic Council. The process involves multiple meetings with the Nordic Council, including to discuss priorities. 


\section{Example - Budget 2018}

As shown in the table below, the MR-SAM budget is the largest item, but other councils of ministers receive funding via the priority budget (see page 16) for inter-sectoral initiatives. The MR-SAM budget also covers international activities, the Nordic Council of Ministers Secretariat and information activities - i.e. areas not covered by a specific council of ministers.

The other main budget items are education and research, culture and business, energy and regional policy (sustainable growth).

\section{The Nordic budget by council of ministers, $\%$}

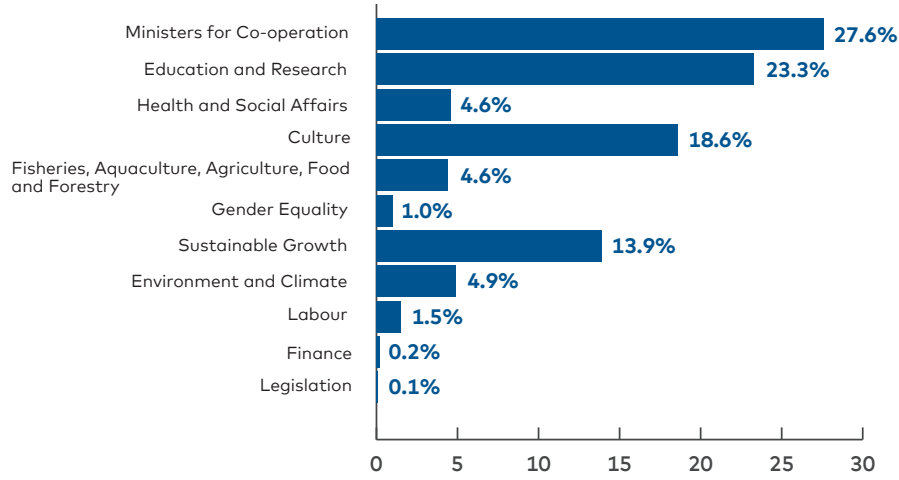




\section{Co-operation between the Presidency and the Secretariat}

Co-operation between the Presidency and the Secretariat is based on close working relations and mutual trust. It is essential that both keep each other informed of all important ongoing activities and initiatives. Agendas for meetings are drawn up in close consultation between the Presidency and the Secretariat, based on proposals submitted by the Secretariat. The Secretariat is responsible for convening meetings and for drawing up and sending out relevant materials. In advance of the meetings, e.g. of the councils of ministers or committees of senior officials, the Presidency and Secretariat inform each other of proposals they wish to submit.

\section{Inter-sectoral co-operation}

A number of projects transcend traditional sectoral boundaries and involve multiple councils of ministers and departments. These projects are coordinated by an adviser, whose role is to ensure that all relevant specialist areas are involved. Examples include the Nordic Committee for Children and Young People (NORDBUK) and the working groups on sustainable development, human trafficking and gender equality. 


\section{Languages and the Nordic Council of Ministers}

All employees of the Nordic Council of Ministers are expected to speak and write one of the Scandinavian languages (Danish, Norwegian or Swedish). As per longestablished practice, these are the official working languages of the Council of Ministers. Certain documents are also translated into Finnish, Icelandic and English. Interpreters work at meetings of the councils of ministers and other meetings as required. This is coordinated by the Translation and Interpretation Unit, part of the Secretariat's Communications Department. English is used as a working language in international contexts. 



\section{Nordic Council}

\section{About the Nordic Council}

Like the Nordic Council of Ministers, the Nordic Council promotes Nordic synergy but at parliamentary level. This is done primarily by developing proposals and by submitting statements and questions to either the Council of Ministers or to one or more of the national governments.

The Nordic Council consists of $87 \mathrm{MPs}$ from the Nordic countries. The plenary Session is the Nordic Council's supreme decision-making organ. The Nordic Council mainly makes decisions or issues statements at its two annual Sessions - an ordinary Session held in late October or early November, and a theme Session in spring. As mentioned above, the Nordic Council approves the budget of the Nordic Council of Ministers at its autumn Session. Between Sessions, the Presidium of the Nordic Council is the decision-making body. The Presidium has four subcommittees, all of which concentrate on particular areas. The Nordic Council and Nordic Council of Ministers work together in several different ways. 


\section{Working with the Nordic Council}

\section{Recommendations, statements and reports/ considerations}

The Nordic Council draws up and submits recommendations, presentations and proposals to the Nordic Council of Ministers or one or more of the Nordic governments. In general, the Secretariat is responsible for responding to recommendations made to the Nordic Council of Ministers, while the Presidency responds to recommendations made to the governments. The recommendations are then delegated out to departments of the Secretariat, which coordinate responses (also known as statements) for the areas they cover. The responses must be approved by the relevant council of ministers. On inter-sectoral matters, the adviser must consult with all relevant sectors.

As a result of a new process adopted by MR-SAM and the Presidium of the Nordic Council in February 2015, responses to recommendations are issued on an ongoing basis and within 12 weeks. The responses indicate whether the Nordic Council of Ministers thinks the recommendation has been complied with or is impossible to comply with. The Nordic Council then decides whether this response is good enough - in which case, the case is considered closed - or whether it wishes to look into it some more. If the Nordic Council chooses to pursue the matter, a political dialogue is initiated. This usually takes the form of a minister from the Presidency discussing the matter 
with MPs at a relevant committee meeting or a Session. Following this political dialogue, a decision is taken on the recommendation.

The Nordic Council studies audit reports from the Nordic Council of Ministers as part of its verification and followup function in relation to the Council of Ministers' activities.

\section{Written questions}

Members of the Nordic Council have the right to submit questions to the governments or the Nordic Council of Ministers. These questions must relate to Nordic co-operation and must not be solely national in nature. Written questions must be answered within six weeks.

\section{Nordic Council of Ministers' proposals}

The Nordic Council of Ministers' proposals are submitted to the Nordic Council by the Council of Ministers or one of the Nordic governments, usually at the Session. The problems addressed must be major or important, e.g. budgets and action plans. They must come from one of the national governments, even though the Council of Ministers formally submits them. 


\section{The Nordic Council prizes}

Every year, the Nordic Council awards prizes for literature, music, film and the environment. The latest addition is the Children and Young People's Literature Prize, which has been awarded since 2013. The awards ceremony is usually broadcast on television.

The purpose of the Nordic Council prizes is to raise awareness of Nordic literature, language, music and film. The Environment Prize goes to individuals or organisations for extraordinary initiatives in the field of nature and the environment. Each prize is worth DKK 350,000. The Nordic Council of Ministers is responsible for the administration of the prizes. 


\section{Useful documents and abbreviations}

\section{Useful documents and systems}

The Helsinki Treaty - on co-operation between Denmark,

Finland, Iceland, Norway and Sweden

Agreement on the legal status of the secretariats - of the Nordic Council of Ministers and the Nordic Council

Agreement on the legal status of institutions - between Denmark, Finland, Iceland, Norway and Sweden on the legal status of Nordic institutions and their staff Rules of procedure for the Nordic Council of Ministers Rules of procedure for the Nordic Council of Ministers' Secretariat Institution Manual - Manual for the operations of the Nordic institutions

\section{www.norden.org}

Website of the Nordic Council of Ministers and Nordic Council. Features news and information about events and publications, more detailed information on Nordic cooperation and contact information for relevant individuals. 


\section{Abbreviations}

CBSS

GSK

HRAJ

KOMM

$\mathrm{KR}$

KV

MR-A

MR-DIGITAL C MR-FINANS

MR-FJLS

MR-JÄM

MR-K

MR-LAG

MR-MK

MR-VAEKST

MR-S

MR-SAM

MR-U

NMRS

NR

NSK

VK

EK-xx
Council of the Baltic Sea States

Office of the Secretary General (Nordic Council of Ministers)

Department for Human Resources, Administration and Law

Communications Department

Department for Culture and Resources

Department for Knowledge and Welfare Council of Ministers for Labour

Council of Ministers for Digitalisation

Council of Ministers for Finance Nordic Council of Ministers for Fisheries, Aquaculture, Agriculture, Food and Forestry Council of Ministers for Gender Equality Council of Ministers for Culture Council of Ministers for Legislative Affairs Council of Ministers for the Environment and Climate

Council of Ministers for Sustainable Growth Council of Ministers for Health and Social Affairs Council of Ministers for Nordic Co-operation Council of Ministers for Education and Research Nordic Council of Ministers Secretariat Nordic Council Committee for Nordic Co-operation Department for Growth and Climate Committees of Senior Officials 


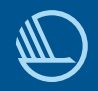

Nordic Council of Ministers

Nordens Hus

Ved Stranden 18

DK-1061 Copenhagen

www.norden.org

ANP 2018:796

ISBN 978-92-893-5724-1 (PRINT)

ISBN 978-92-893-5725-8 (PDF)

ISBN 978-92-893-5726-5 (EPUB) 